\title{
Telerehabilitacja dorosłych pacjentów korzystających $z$ aparatów słuchowych i/lub implantów ślimakowych
}

\section{Telerehabilitation of adult patients with hearing aids and/or cochlear implants}

\author{
Agnieszka Pankowska, Joanna Rostkowska, Henryk Skarżyński \\ Instytut Fizjologii i Patologii Słuchu, Światowe Centrum Słuchu, Klinika Rehabilitacji, Warszawa/Kajetany \\ Adres autora: Agnieszka Pankowska, Światowe Centrum Słuchu, Klinika Rehabilitacji, ul. Mokra 17, Kajetany, \\ 05-830 Nadarzyn, e-mail: a.pankowska@ifps.org.pl
}

\begin{abstract}
Streszczenie
Telemedycyna to najnowsza forma opieki zdrowotnej, łącząca w sobie elementy telekomunikacji, informatyki oraz medycyny. Osiągnięcia techniczne w połączeniu z doświadczeniem specjalistów implikują powstawanie programów opieki nad pacjentami $\mathrm{w}$ różnym wieku i z różnego typu problemami zdrowotnymi realizowanych „na odległość”. Telerehabilitacja umożliwia dostarczenie odbiorcy usług rehabilitacyjnych z wykorzystaniem sieci połączeń telekomunikacyjnych i Internetu. W odniesieniu do osób $z$ wada słuchu, w tym korzystających $z$ tradycyjnych aparatów słuchowych i/lub implantów słuchowych, działania o charakterze rehabilitacyjnym wpisują się także w programy określane mianem teleaudiologii i telezdrowia. W artykule przedstawiono najważniejsze doniesienia z literatury (artykułów, prac doktorskich, doniesień wstępnych, streszczeń i prezentacji) oraz raportów $\mathrm{z}$ realizacji programów unijnych, które podsumowują badania i działania praktyczne skierowane do pacjentów dorosłych korzystających z protez słuchowych w ramach szeroko rozumianej telerehabilitacji. Przedstawione zostały modele postępowania, prowadzący i odbiorcy programów, formy świadczenia usług oraz wrażenia uczestników terapii organizowanych w systemie "tele”. Wykorzystanie technologii w przygotowaniu i prowadzeniu opieki nad osobami z wada słuchu stanowi istotną pomoc zwłaszcza w rejonach, gdzie brak specjalistów lub ograniczony dostęp do nich determinuje skuteczność stosowania określonego postępowania medycznego.
\end{abstract}

Słowa kluczowe: telemedycyna • telerehabilitacja • dorośli • implanty słuchowe • aparaty słuchowe

\begin{abstract}
Telemedicine is the newest form of healthcare combining elements of telecommunications, informatics and medicine. Technical progress in connection with expert experience imply the rise of the remote programs of care for patients from different age groups and with different types of health problems. Telerehabilitation enables the delivery of rehabilitation services to a user through telecommunications network and the Internet. In relation to persons with hearing loss, including users of hearing aids and/or hearing implants, rehabilitation activities are also included in programs categorized as teleaudiology or telehealth. This paper presents the overview of the most important reports from literature (papers, doctoral theses, preliminary reports, abstracts and presentations) as well as reports of implementation of EU programs, which summarize research and practical actions addressed to adult users of auditory prostheses within broadly understood telerehabilitation. It discusses implemented management models, recipients and providers of programs, forms of service delivery and impressions of the participants of therapy programs organized in a 'tele' format. The utilization of technology to organize and provide care for persons with hearing loss brings about significant benefits, especially in places were lack of specialists or limited access to them determine the efficiency of specific medical management programs.
\end{abstract}

Key words: telemedicine $\bullet$ telerehabilitation $\bullet$ adults $\bullet$ hearing implants $\bullet$ hearing aids

\section{Wprowadzenie}

Gwałtowny rozwój technologii teleinformatycznych przyczynił się do powstania i dynamicznego rozwoju dziedziny określanej mianem telemedycyny. Jest to najnowsza forma opieki zdrowotnej, łącząca w sobie elementy telekomunikacji, informatyki oraz medycyny. Powszechny dostęp do komputerów, ale przede wszystkim nowoczesna technologia wykorzystująca szybkie algorytmy cyfrowego przetwarzania i kompresji sygnałów, umożliwiają przesyłanie obrazów i dźwięku, a co za tym idzie także interaktywną transmisję audiowizualną o wysokiej jakości. 
Dzięki wykorzystaniu połączenia internetowego możliwa jest też zdalna kontrola nad urządzeniami [1]. Osiągnięcia techniczne w połączeniu $\mathrm{z}$ doświadczeniem specjalistów implikują powstawanie programów opieki nad pacjenta$\mathrm{mi} \mathrm{w}$ różnym wieku i z różnego typu problemami zdrowotnymi realizowanych „na odległość”, którym nadaje się przedrostek „tele”. W literaturze spotkać można określenia: telezdrowie, telemedycyna, teleaudiologia, telerehabilitacja, teleterapia, telemowa, teletrening [2]. Doktor Mark Krumm definiuje pojęcie 'telezdrowie' jako świadczenie usług zdrowotnych z jednej lokalizacji do innej z wykorzystaniem środków telekomunikacyjnych (ang. telecommunications medium) takich jak Internet, sieć komputerowa, telefony i urządzenia pokrewne. Usługi te przypisuje pewnym dziedzinom, m.in. kardiologii, radiologii, geriatrii. Postuluje natomiast oddzielenie pojęcia 'telemedycyna', które dotyczy przede wszystkim lekarzy, od 'telezdrowia', które obejmuje wszystkie osoby działające w ochronie zdrowia [3]. Pod pojęciem 'telerehabilitacja' (teletrening) należy więc rozumieć postępowanie służące dostarczeniu odbiorcy usług rehabilitacyjnych na odległość z wykorzystaniem urządzeń, sieci połączeń telekomunikacyjnych i Internetu. Na podstawie dokonanego przeglądu literatury (artykułów, prac doktorskich, doniesień wstępnych, streszczeń i prezentacji oraz raportów z realizacji programów unijnych) można sądzić, że prowadzona na odległość diagnostyka i działania praktyczne skierowane do pacjentów dorosłych korzystających z protez słuchowych są coraz chętniej proponowaną alternatywą dla opieki realizowanej w ośrodkach stacjonarnych. Za szczególnie aktywne w tym zakresie należy uznać Stany Zjednoczone i Australię, skąd pochodzi większość doniesień.

\section{Modele postępowania}

$\mathrm{W}$ telerehabilitacji, podobnie jak w innych formach teleopieki i telemedycyny, stosowane są 4 podstawowe modele postępowania: synchroniczny, asynchroniczny, mieszany i samosprawdzenie [4]. O kwalifikacji świadczonej usługi do odpowiedniego modelu decyduje wykorzystywana technologia (urządzenia i materiały).

Model synchroniczny dotyczy działań, które obejmują równoległy, jednoczesny, bezpośredni kontakt specjalisty (terapeuty, lekarza, technika, inżyniera) z odbiorcą (pacjentem) podczas wypełniania zadań programu opieki. W tym celu obie strony powinny mieć jednoczesny dostęp do systemów i urządzeń zapewniających właściwą prędkość transferu informacji (np. szybkie łącza), urządzeń, programów lub aplikacji, które zapewniają właściwą jakość obrazu i dźwięku. W tym modelu często spotykaną formą jest możliwość zdalnej kontroli opiekuna (prowadzącego) nad urządzeniami odległymi. Jeśli pozwala na to dostępna technologia, można włączyć do współdziałania jednocześnie więcej niż jednego odbiorcę (pacjenta). Taką formułę postępowania wobec pacjentów korzystających z implantów ślimakowych, w tym osób dorosłych, realizuje się m.in. w Światowym Centrum Słuchu [5].

Model asynchroniczny dotyczy działań, które nie wymagają jednoczesnego, bezpośredniego kontaktu specjalisty z odbiorcą. Po otrzymaniu instrukcji od specjalisty prowadzącego, np. w formie e-maila, listownej bądź bezpośrednio podczas stacjonarnej wizyty w odpowiednim ośrodku, rozpoczyna się udział $\mathrm{w}$ programie - pacjent wykonuje odpowiednie zalecenia w dogodnym dla siebie czasie. Również specjalista dokonuje oceny wyników uzyskanych przez pacjenta w dogodnym dla siebie czasie. W zależności od tych wyników przekazuje pacjentowi dalsze zalecenia. W praktyce pacjent ma dostęp do odpowiedniej strony internetowej lub zamieszczonej na niej zakładki, gdzie znajduje się: kwestionariusz, test, materiał informacyjny, edukacyjny itp., bądź otrzymuje zestaw materiałów, konkretnych ćwiczeń itp. zarejestrowanych na płytach CD lub DVD. Przykładem z Polski może być program opatrzony tytułem „Domowa Klinika Rehabilitacji” [6]. Model ten jest łatwiejszy do realizacji, gdyż nie wymaga jednoczasowej obecności obydwu stron oraz oszczędza czas specjaliście, który nie śledzi przebiegu konsultacji, a jedynie analizuje wyniki.

Model mieszany obejmuje postępowanie, które w pierwszym etapie ma charakter instruktażowy lub konsultacyjny - wówczas bezpośredni, jednoczesny kontakt ze specjalistą (opiekunem) jest niezbędny do włączenia pacjenta do programu (konsultacja wstępna, instrukcja, wskazanie urządzeń, materiałów i potrzebnych pomocy) i może być realizowany podczas wizyty w ośrodku, poprzez zalogowanie się na stronie wskazanego przez specjalistę serwisu internetowego lub bezpośrednie połączenie ze specjalistą $\mathrm{z}$ wykorzystaniem interaktywnej transmisji audiowizualnej. W drugim etapie pacjent otrzymuje od razu lub kolejno po wypełnieniu uprzednich zadań materiały (ćwiczenia, komentarze, wskazówki itp.), realizuje określone postępowanie, a następnie (zwykle w ustalonych interwałach czasowych) przekazuje specjaliście rezultaty czy wyniki i oczekuje na przesłanie oceny lub wskazań dotyczących dalszego postępowania. Na tym etapie w zależności od specyfiki realizowanych zadań pacjent może być w jednoczesnym, bezpośrednim kontakcie ze specjalistą (zgodnie z założeniami modelu synchronicznego) lub wykonywać zadania w dogodnym dla siebie czasie (zgodnie z założeniami modelu asynchronicznego).

Samosprawdzenie (ang. self-test) - model postępowania, w którym pacjent sam decyduje o poszukiwaniu źródła pomocy lub ma wskazane dostępne źródła i sam przeprowadza ćwiczenia lub testy, zapoznaje się z dostępnymi materiałami informacyjnymi, edukacyjnymi itp. Korzysta wówczas z ogólnie dostępnych materiałów zapisanych na nośnikach, aplikacjach czy na stronach www [4,7-14].

Niezależnie od wybranego modelu nadrzędnym celem opieki w systemie „tele” jest zapewnienie bezpiecznego udziału uczestnikom programu oraz - co najistotniejsze - bezpiecznego, właściwie kodowanego przepływu danych tak, by osoby postronne nie miały do nich wglądu lub dostępu.

\section{Odbiorcy}

Działaniami w ramach programów realizowanych w systemie telerehabilitacji, treningu w warunkach domowych i samosprawdzenia obejmowane są osoby dorosłe korzystające z różnych protez słuchowych (aparatów słuchowych i/lub implantów słuchowych), jak również osoby, które podejrzewają u siebie problemy ze słuchem - są na etapie diagnostycznym, lub osoby, które mają stwierdzony 
niedosłuch, ale nie korzystają z urządzeń wspomagających słyszenie. Ponadto są to osoby, u których problem słuchu jest dominujący, ale współwystępują jednocześnie inne dolegliwości lub schorzenia związane $\mathrm{z}$ wiekiem, problemy z mówieniem, przebyty udar, ograniczona sprawność motoryczna, której towarzyszy niedosłuch czy szumy uszne (korzystające lub nie z aparatów słuchowych) [8-12].

Pauline Mashima i Charles Doarn z Uniwersytetu w Cincinnati zwracają uwagę na fakt, że przy organizacji opieki i włączeniu pacjenta do działań w systemie telerehabilitacji powinny być wzięte pod uwagę różne czynniki, które pozwolą odbiorcy na utrzymanie zainteresowania działaniami specjalisty i reagowanie na jego instrukcje (m.in. możliwości motoryczne, poznawcze pacjenta, współdziałanie rodziny, otoczenia czy swoboda dostępu i obsługi potrzebnych urządzeń) [7].

Wpływ na udział w programach odgrywa także odległość miejsca pobytu pacjenta od ośrodka prowadzącego rehabilitację w systemie stacjonarnym. W większości opisywanych przypadków odbiorcami stają się osoby, które musiałyby pokonywać duże odległości, aby dotrzeć na zajęcia. Także wiek pacjenta oraz jego zaangażowanie $\mathrm{w}$ inne aktywności (naukę, pracę, opiekę nad dziećmi itp.) wpływa na jego zainteresowanie i gotowość do udziału w telerehabilitacji. Uczniowie, studenci, osoby czynne zawodowo stanowią liczne grono beneficjentów takich programów. Warto w tym miejscu podkreślić, że również osoby starsze, samotne lub niemieszkające $\mathrm{z}$ najbliższymi na co dzień coraz chętniej korzystają $\mathrm{z}$ teleopieki.

\section{Specjaliści}

Czynnik ludzki ma w telemedycynie duże znaczenie zarówno przy określaniu odbiorców działań, jak i przy wyborze specjalistów udzielających świadczeń. Specjaliści odgrywają ważną rolę na kolejnych etapach działań: przy planowaniu, wdrożeniu, treningu (ćwiczeniach), ocenie rezultatów. Dla pacjenta jako beneficjenta programu (usługi) najważniejszą rolę odgrywa osoba, z którą ma bezpośredni kontakt. W gronie specjalistów zaangażowanych w telerehabilitację pacjentów z protezami słuchu wymienia się: lekarzy, techników, terapeutów (logopeda, psycholog), rehabilitantów oraz personel innych specjalności: techników komputerowych, administratorów stron, którzy pomagają w sprawnym działaniu usługi, ale nie pozostają w bezpośrednim kontakcie z pacjentem, lecz mogą, jeśli potrzeba - ze specjalistą [15]. David Brennan i Linsey Barker, powołując się na stanowisko prezentowane przez American Speech-Language-Hearing Association and the Canadian Association of Occupational Therapists, wskazują potrzebę właściwego doboru personelu, zwłaszcza uprawnionego do bezpośredniego kontaktu z pacjentem, który powinien cechować profesjonalizm, posiadanie stosownych uprawnień, wykształcenie, właściwe podejście, doświadczenie w pracy z osobami niedosłyszącymi lub niesłyszącymi oraz znajomość obsługi urządzeń i/lub aplikacji wykorzystywanych podczas usług [15]. W znaczącej większości przypadków specjaliści zaangażowani w bezpośredni kontakt z pacjentami pracują w ośrodkach, które świadczą usługi rehabilitacyjne w systemie stacjonarnym i jednocześnie realizują zadania telerehabilitacji, np. ośrodki medyczne, rehabilitacyjne (na oddziałach szpitalnych, samodzielne) itp.

\section{Formy świadczenia usług}

Są one związane $\mathrm{z}$ metodą organizacji postępowania lub programu zawierającego się $\mathrm{w}$ działaniach określanych mianem telerehabilitacji. Do najważniejszych i opisywanych w różnego typu doniesieniach należą:

- kwestionariusze, ankiety (pojedyncze lub w zestawach),

- materiały informacyjne, edukacyjne opracowane w zespołach lub pochodzące $z$ ogólnodostępnych publikacji, wybrane i podzielone na części przez specjalistów,

- wideorozmowy lub wideokonferencje (konsultacje indywidualne on-line, zajęcia rehabilitacyjne on-line w systemie audio-wideo),

- płyty DVD lub CD z materiałami informacyjnymi, edukacyjnymi, ćwiczeniami ułożonymi w kolejności do wykonania w określonym porządku i czasie,

- testy, oceny okresowe,

- grupowe fora dyskusyjne.

Do najbardziej popularnych i najwcześniej wprowadzonych należą kwestionariusze (ankiety). Pacjenci otrzymują je w różnych formach: jako materiał zapisany na nośnikach lub dostępny po zadeklarowaniu udziału w programie (np. po zalogowaniu na odpowiednią stronę internetową, po połączeniu z opiekunem). Są one bardzo popularne jako metoda współpracy z osobami dorosłymi, które otrzymały aparaty słuchowe, i dotyczą zwykle zmian w funkcjonowaniu społecznym, komunikacyjnym, psychicznym, jakie wywołał ubytek słuchu, oraz zmian, jakie następują w czasie adaptacji do korzystania $\mathrm{z}$ aparatu/ów słuchowego/wych oraz doświadczeń z dłuższego okresu korzystania z tych urządzeń.

Materiały informacyjne i/lub edukacyjne są udostępniane pacjentom $\mathrm{w}$ formie przygotowanych przez specjalistów artykułów, rozdziałów książek itp., wybranych i ułożonych w odpowiedniej kolejności stosownie do aktualnych potrzeb pacjenta, wynikających najczęściej z okresu korzystania z protez słuchowych (najliczniej: aparatów słuchowych). Zadaniem pacjenta jest zapoznanie się z nimi na własne potrzeby, w celu zaspokojenia wiedzy, uzyskania odpowiedzi na najbardziej nurtujące pytania bądź zapoznawanie się z kolejnymi partiami materiału, a po sprawdzeniu przez opiekuna, że działanie to miało miejsce (np. $\mathrm{w}$ formie krótkiej ankiety, quizu, opisu własnych doświadczeń), pacjent otrzymuje kolejną część, a po analogicznym zweryfikowaniu przez opiekuna, że wypełnił to zadanie, włączany jest do działań terapeutycznych już jako świadomy uczestnik lub poprzestaje na wiedzy teoretycznej, którą chce samodzielnie weryfikować w sytuacjach życiowych.

Wideorozmowy i wideokonferencje należą do metod synchronicznych i mogą być realizowane dzięki wykorzystaniu interaktywnej transmisji audiowizualnej różnego rodzaju łączy internetowych. Wówczas pacjent musi posiadać multimedialny komputer $\mathrm{z}$ oprogramowaniem do wideokonferencji i kamerę komputerową. Warto zaznaczyć, że duży wpływ na właściwie przebiegającą konsultację czy sesję (jakość obrazu, dźwięku) będzie miała w takim przypadku - poza urządzeniami - dostępna prędkość połączenia. Poprzez wideokonferencje internetowe można zbierać wyniki, wysyłać pliki, dzielić się informacjami, korzystać z ilustracji, list słownych, zdaniowych, które mogą być wyświetlane na ekranie komputera odbiorcy. 
Płyty DVD lub CD z zapisanymi materiałami informacyjnymi, edukacyjnymi, ćwiczeniami przekazywane są pacjentom podczas bezpośredniego kontaktu z terapeutą. Przed rozpoczęciem programu specjalista nawiązuje kontakt z pacjentem i określa czas, w którym mają być realizowane kolejne zadania. Specjalista ustala także terminy, w których omawiane będą wyniki uzyskane przez pacjenta.

Jeżeli pacjent ma problemy, wątpliwości, może przedyskutować je ze specjalistą za pośrednictwem wybranej formy kontaktu (bezpośrednio, pośrednio) lub do pomocy włączana jest inna osoba, która towarzyszy pacjentowi podczas wypełniania zadań (ćwiczeń) - stosownie do możliwości: najbliższy krewny, wolontariusz czy choćby student logopedii.

Testy i okresowe samosprawdzenie pacjent może wypełniać samodzielnie lub we współpracy ze specjalistą po zalogowaniu do systemu, na stronie internetowej lub podczas konsultacji on-line. Forma przekazania instrukcji wykonania testu jest dowolna. Instrukcja może mieć charakter pisemny lub ustny, powinna być krótka, zrozumiała, dostosowana do zadań testu.

Grupowe fora dyskusyjne prowadzone są dla pacjentów, którzy rozpoczynają korzystanie z aparatów słuchowych lub są już doświadczonymi ich użytkownikami. Mogą być realizowane w systemie on-line bezpośrednio oraz pośrednio w formie „rozmowy pisanej”. Do forum dostęp mają pacjenci, którzy zgłosili chęć udziału w programie i zobowiązują się do poszanowania zdania innych oraz przestrzegania regulaminu forum. Nad przebiegiem dyskusji czuwa jeden specjalista lub różni specjaliści - stosownie do potrzeb grupy, tematu. Celem działań jest wymiana doświadczeń, wskazanie rozwiązań przez osoby dotknięte takim samym problemem. Jest to forma szczególnie popularyzowana wśród osób w wieku podeszłym $\mathrm{z}$ nabytym, stopniowo postępującym ubytkiem słuchu, które otrzymały lub użytkują już aparaty słuchowe [4,7-14].

\section{Wrażenia uczestników telerehabilitacji}

Zarówno wśród pacjentów uczestniczących w programach telerehabilitacji, jak i wśród realizujących je specjalistów prowadzono badania dotyczące subiektywnej oceny tych programów. Pacjenci na co dzień obsługujący komputer lub korzystający z Internetu nie zgłaszali uwag do tej formy współpracy. Nie zauważali istotnych różnic między formułą stacjonarną a realizowaną „na odległość”. Ci odbiorcy, którzy jednocześnie uczyli się podstaw obsługi sprzętu (komputera, kamery, odtwarzacza), tego typu proces rehabilitacji uznawali za bardziej atrakcyjny. Istotną rolę odgrywał także czynnik poczucia prywatności w relacji ze specjalistą. Pacjenci nie zgłaszali istotnych różnic w porównaniu $\mathrm{z}$ bezpośrednim (przez co należy rozumieć „w gabinecie”) kontaktem $\mathrm{z}$ terapeutą. Wobec pozytywnych reakcji ze strony pacjentów także terapeuci (logopedzi) chętniej angażowali się w wykorzystywanie "technologii” w swojej praktyce. Zauważali oni, że potrzeby pacjentów jako odbiorców telepomocy implikują konieczność modernizacji technik stosowanych w bezpośredniej współpracy. Fizyczna nieobecność specjalisty (zwłaszcza w modelach asynchronicznych) zachowuje element, jakim jest „czynnik ludzki”, jak i nie zmniejsza efektywności usług świadczonych w systemie telezdrowia [15]. Specjaliści prowadzący trening dotyczący problemów artykulacyjnych, jakości mowy, terapii głosu zgłaszali, że jakość przekazu ma duże znaczenie przy wysłuchiwaniu wypowiedzi pacjenta (np. z nosowaniem, wadliwą realizacją głosek, obniżoną motoryką artykulatorów). Wpływa ona na właściwą ocenę problemu i zmian następujących dzięki prowadzonym ćwiczeniom. Na podstawie analizowanych doniesień można wnioskować, że obie strony procesu telerehabilitacji nie zgłaszały znaczących zastrzeżeń do tej formy pomocy, które wpływałyby na efektywność realizacji programów rehabilitacji, i były zainteresowane dalszym udziałem $\mathrm{w}$ takich programach $[4,7]$.

\section{Podsumowanie}

Po przeprowadzeniu analizy informacji zawartych w publikacjach związanych $\mathrm{z}$ tematem telezdrowie, telemedycyna, teleaudiologia, telerehabilitacja należy zauważyć, że terminy te oznaczają różne formy i modele postępowania. Elementem łącznym jest dostarczenie uczestnikowi programu pomocy w miejscu zamieszkania lub ośrodku położonym najbliżej tego miejsca. Drogą pośredniego lub bezpośredniego kontaktu z pacjentem specjalista ma możliwość przekazania informacji, prowadzenia działań diagnostycznych, terapii, działań oceniających lub monitorujących zastosowaną metodę leczenia. Telerehabilitacja to również współdziałanie $\mathrm{z}$ rodziną i najbliższym otoczeniem pacjenta.

\section{Wnioski}

Najważniejsze wnioski płynące z publikacji objętych przeglądem to:

- Jakość usług realizowanych w systemie „tele” musi odpowiadać jakości usług świadczonych „twarzą w twarz”, czyli w bezpośrednim kontakcie z pacjentem.

- Celem rozwoju programów opieki, terapii realizowanych w systemie „tele” powinno być uwzględnienie różnego typu ograniczeń związanych $\mathrm{z}$ wiekiem, chorobą, metodą leczenia.

- Doświadczenie specjalistów powinno być łączone z możliwościami, jakie dają nowoczesne technologie, w celu rozwijania programów telerehabilitacji. Ma to znaczenie zwłaszcza w miejscach, gdzie obserwowany jest brak specjalistów lub dostęp do nich determinuje skuteczność zastosowanego postępowania medycznego.

- Procedury postępowania powinny gwarantować bezpieczeństwo pacjentowi i uniemożliwiać dostęp osób trzecich do danych, wyników, przebiegu sesji, konsultacji.

- Obserwowanie zajęć, nagrywanie, fotografowanie powinno odbywać się wyłącznie po uprzedzeniu i za zgodą uczestników.

- Jakość i przepustowość łącza stanowi ważny element telerehabilitacji. Konieczne jest zapewnienie odpowiedniej jakości transmisji obrazu, głosu oraz danych.

- Przy organizowaniu opieki w systemie telerahabilitacji powinno się zwracać szczególną uwagę na to, aby sprzęt stosowany po stronie odbiorcy nie wymagał dużych nakładów finansowych i/lub profesjonalnej obsługi.

Publikacja powstała $w$ związku z realizacja projektu pn. „Zintegrowany system narzędzi do diagnostyki i telerehabilitacji schorzeń narządów zmysłów (słuchu, wzroku, mowy, równowagi, smaku, powonienia)" INNOSENSE, wspólfinansowanego przez Narodowe Centrum Badań i Rozwoju w ramach Programu STRATEGMED. 


\section{Piśmiennictwo:}

1. Wąsowski A, Skarżyński H, Bruski Ł, Lorens A, Obrycka A, Walkowiak A i wsp. Metoda zdalnego dopasowania implantu (telefitting) w Ogólnopolskiej Sieci Teleaudiologii. Nowa Audiofonologia, 2012; 1(3): 39-43.

2. Houston K, Fleming A, Brown K. Telepractice for individuals with hearing loss. Prezentacja ze strony: www.asha.org/ telepractice.

3. Fabry D. Applications of Telehealth for hearing care. Audiology Today, 2010; 22(5): 18-26.

4. Swanepoel D, Hall J. A Systematic review of Telehealth applications in audiology. TELEMEDICINE and e-HEALTH, 2010; 16(2): 181-200.

5. Pankowska A, Solnica J, Skarżyński H. Telerehabilitacja - nowa forma pomocy pacjentom korzystającym z systemu implantu ślimakowego w ramach programu opieki pooperacyjnej. Nowa Audiofonologia, 2012; 1(3): 35-8.

6. Solnica J, Pankowska A, Wasowski A i wsp. Home Rehabilitation Clinic (HRC) - the proposal of solution of organizing rehabilitation close to patient's home. 10 \{th European Symposium on Pediatric Cochlear Implantation, 2011; 261-4.

7. Mashima P, Doarn Ch. Overview of Telehealth activities in speech-language oathology. TELEMEDICINE and e-HEALTH, 2008; 14(10): 1101-7.

8. Thorén E, Svensson M, Törnqvist A, Andersson G, Carlbring P, Lunner T. Rehabilitative online education versus Internet discussion group for hearing aid users: A randomized controlled trial. J Am Acad Audiol, 2011; 22: 274-85.
9. Ferguson M. Delivery of hearing healthcare and education using the Internet. ENT\& Audiology News, 2012; 21(3): 68-70.

10. Coutinho de Macedo E, Capovilla F, Cleber D, Orsati F, Nikaedo C. Development of a test battery to assess deaf language skills via www. Proceedings of the WebMedia \& LA-Web 2004. Joint Conference 10th Brazilian Symposium on Multimedia and the Web, 2 \{nd Latin American Web Congress, 2004: $1-7$.

11. Glykas M, Chytas P. Technology assisted speech and language therapy. Int J Med Inform, 2004; 73: 529-41.

12. Manchaiah VK, Stephens D, Andersson G, Rönnberg J, Lunner T. Use of the 'patient journey' model in the internet-based pre-fitting counseling of a person with hearing disability: study protocol for a randomized controlled trial. Trials, 2013; 14: 25 .

13. Ferguson M, Henshaw H. Auditory training as an intervention for adults with hearing loss: the current state of play. ENT \& Audiology News, 2011; 20(4): 104-6.

14. Schoenberg M, Ruwe W, Dawson K, McDonald N, Houston B, Forducey P. Computer-based cognitive rehabilitation teletherapy program and a face-to-face rehabilitation program. Professional Psychology: Research and Practice, 2008; 39(2): 169-75.

15. Brennan D, Barker L. Human factors in the development and implementation of telerehabilitation systems. J Telemed Telecare, 2008 ; 14: 55-8.

16. Thoren SE. Internet interventions for hearing loss. Linköping, Linköping University, 2014. 